\title{
Pengaruh Dongeng Dalam Peningkatan Emosi Positif Anak Usia Prasekolah
}

\author{
Annisa Trihastuti \\ annstrhstuti@gmail.com \\ Yansa Alif Mulya \\ yansaalif18@gmail.com
}

\author{
Zaid Abdillah \\ zaid.malang.alhanif@gmail.com \\ Fina Hidayati \\ finahi@psi.uin-malang.ac.id
}

Fakultas Psikologi, Universitas Islam Negeri Maulana (UIN) Malik Ibrahim Malang, Indonesia

\begin{abstract}
Abstrak
Penelitian ini bertujuan mengetahui Pengaruh Dongeng dalam perkembangan emosi positif anak usia prasekolah di TK Muslimat NU 21. Metode penelitian yang digunakan adalah metode eksperimen pretest-posttest. Subjek penelitian adalah 40 siswa TK dengan menggunakan dua kelompok variabel yani kontrol dan eksperimen. Terdapat empat emosi positif (Interested, Excited, Inspired, Strong, Active) dalam penelitian ini. Hasil Penelitian menunjukkan terdapat perubahan sebesar 41,2\% pada kelompok eksperimen dan 9,34\% pada kelompok kontrol. Aspek yang mengalami perbuhan signifikan adalah aspek Interested, Inspired, strong, dan active.
\end{abstract}

Kata kunci: Dongeng; Emosi positif; prasekolah

Psikoislamika : Jurnal Psikologi dan Psikologi Islam (JPPI) Volume 15. Nomor 2, Tahun 2018. copyright (C) 2018. Pusat Penelitian dan Layanan Psikologi.

\section{PENDAHULUAN}

Manusia mengalami perkembangan sepanjang hidupnya. Perkembangan manusia dibagi beberapa periode. Diantaranya, periode prakelahiran, masa bayi, masa kanak-kanak awal, masa kanak-kanak pertengahan dan akhir, masa remaja, masa dewasa awal, masa dewasa menengah, dan masa dewasa akhir Masa kanakkanak awal atau masa anak usia prasekolah adalah masa ketika anak berusia 2 hingga 5 atau 6 tahun (Santrock, 2011).

Perkembangan emosi pada masa prasekolah berkaitan dengan meningkatnya pemahaman terhadap emosi (Santrock 2011). Pada masa ini perkembangan emosi anak berkaitan dengan kemampuan tertentu. Berupa pengenalan ekspresi wajah terhadap emosi tertentu, kemampuan mendekripsikan emosi, kemampuan merefleksikan emosi, dan menentukan emosi yang akurat. Penelitian lain juga menyebutkan bahwa emosi anak ini akan membentuk perilaku prososial ( Ensor dalam Santrock, 2011).

Lima tahun pertama kehidupan manusia merupakan peluang penting untuk meletakkan dasar-dasar perkembangan yang sehat (Cooper, 2009).

Penelitian pada anak usia dini menunjukkan bahwa terdapat dampak dalam perkembangan sosial dan emosi sepanjang kehidupan di lima tahun awal (Cooper, 2009). Berarti perkembangan emosi anak dikemudian hari akan dbanyak dipengaruhi dari perkembangan emosi sebelumnya. Pemahaman emosi anak prasekolah berpengaruh terhadap perkembangan emosi selanjutnya (Garner, 2011).

Perkembangan sosial dan emosi pada usia dini yang baik akan berpengaruh terhadap masa selanjutnya(Garner, 2011). Menurut Penelitain Garner (2011), Sosialisasi emosi pada anak usia 4 tahun berpengaruh pada 4 tahun kemudian. Hal 
ini menunjukkan bahwa keadaan emosi anak pada usia kanak-kanak tengah dan akhir dipengaruhi saat usia dininya. Pengetahuan emosi yang baik akan mengakibatkan pertumbuhan emosi yang baik juga pada selanjutnya (Garner, 2011). Pada kenyatannya , masih terdapat kasus pada anak-anak usia sekolah berkaitan dengan emosinya. Seperti yang dilansir dari kompas.com, pada Januari 2018, terjadi penganiayaan yang dilakukan siswa SD kelas 6 terhadap adek kelasnya, kelas 2 SD hingga harus dilarikan ke rumah sakit dan dilakukan perawatan intensif, akibat kemarahan kejadian gol cetak bunuh diri. Maka pendidikan sejak masa usia dini menjadi hal yang penting terkait dengan perkembangan emosinya., untuk mencegah hal ini terjadi.

Dongeng merupakan suatu cara untuk mengoptimalkan perkembangan emosi anak (Beaty, 2013). Cerita yang disampaikan, akan memperkuat pengetahuan mereka mengenai emosi. Mulai dari karakter tokoh, alur cerita, hingga gaya penyampaian pendongeng yang menarik. Dongeng akan menjadi hal yang efektif karena terjadi komunikasi kepada anak terhadap pemahaman emosinya (Garner, 2011). Emosi positif yang diajarkan dalam dongeng akan terkomunikasikan didalamnya.

Dalam penelitian sebelumnya, disebutkan bahwa Dongeng menjadi bagian penting dari pendidikan prasekolah kurikulum dan praktek awal (Gnjatovic, 2015). Cerita dalam dongeng akan menjadi asset dalam perkembangan sosialemosi dan motorik. Peneiltian lain juga menunjukkan bahwa dongeng mampu membantu regulasi diri (Gnjatovic, 2015). Sejalan dengan hal tersebut dongeng menurut Garzotto (2010) membantu perkembangan komunikasi, rekognasi, kemampuan recall, dan membantu mendorong hubungan antar sebaya.

\section{KERANGKA KAJIAN TEORITIK}

\section{Emosi}

Makna emosi banyak dikaji oleh para psikolog, dan banyak mendapatkan tempat dari pengkajian mereka, karena dianggap sebagai bagian yang penting dan menarik dalam kehidupan manusia ini. Sukmadinata (2002: 80) misalnya, ia memberikan definisi emosi sebagai perpaduan dari beberapa perasaan yang mempunyai intensitas yang relatif tinggi dan menimbulkan suatu gejolak suasana batin.
Seperti halnya perasaan, emosi juga membentuk suatu kontinum, bergerak dari emosi positif hingga yang bersifat negative. Sementara Crow \& Crow dalam Sunarto \& Hartono (2002: 149), memberikan pengertian emosi sebagai pengalaman afektif yang disertai penyesuaian diri dalam diri individu tentang keadaan mental dan fisik, dan berwujud suatu tingkah laku yang tampak. Dengan demikian, dapat dipahami bahwa emosi adalah perasaan batin seseorang, baik berupa pergolakan pikiran, nafsu, keadaan mental dan fisik yang dapat muncul atau termanifestasi ke dalam bentuk-bentuk atau gejala-gejala seperti takut, cemas, marah, murung, kesal, iri, cemburu, senang, kasih sayang, dan ingin tahu. Dalam kaitannya dengan proses sosial, emosi dapat muncul sebagai akibar adanya hubungan atau interaksi sosial antara individu, kelompok, dan masyarakat. Emosi dapat muncul sebagai reaksi fisiologis, perasaan, dan perubahan perilaku yang tampak. Emosi pada anak usia dini lebih kompleks dan nyata, karena anak cenderung mengekspresikan emosinya dengan bebas dan terbuka.

Secara umum emosi mempunyai fungsi untuk mencapai suatu pemuasan, pemenuhan, atau perlindungan diri, atau bahkan kesejahteraan pribadi pada saat keadaan tidak nyaman dengan lingkungan atau objek tertentu.

\section{Karakteristik Emosi Anak}

Karakteristik emosi anak usia dini yang sering terlihat seperti emosi anak berlangsung singkat lalu tiba-tiba berhenti. Emosi anak usia dini sifatnya mendalam, tetapi mudah berganti, dan selain sifatnya terbuka juga lebih sering terjadi. Sebagai contoh, anak kalau sedang marah, dia akan menangis kerasa atau berteriak-teriak, tetapi kalau kemauannya dituruti atau terpenuhi, maka tiba-tiba tangisannya berhenti dan biasanya langsung tertawa.

Perkembangan emosi diwarnai oleh kematangan dan lingkungan sekitar seperti kemampuan berpikir. Kecemasan anak akibat dari perceraian orang tuanya akan sama reaksinya pada semua anak usia dini, sama seperti saat anak-anak seusia tersebut ditinggalkan ibunya saat awal masuk sekolah.

\section{Dongeng}

Menurut Kamus Besar Bahasa Indonesia, Dongeng adalah cerita yang tidak benar-benar terjadi. Sejalan dengan itu Menurut Huck, Hepler, 
dan Hickman dongeng merupakan narasi yang berbentuk tulis atau lisan yang ada turun menurun (Ardini, 2012). Menurut Priyono dongeng adalah cerita khayalan yang dibuat-buat dan dapat diambil manfaatnya (Ardini, 2012).

Dongeng menurut Kogh (1998) telah digunakan berabad-abad sebagai alat komunikasi yang mengandung sebuah kejadian, karakter dan bagaimana tingkah laku karakter tersebut. Dongeng adalah cara tradisional yang ada dalam praktek sekolah, cerita dalam dongeng akan mempengaruhi bagaimana anak-anak melihat dan mengerti dunia disekitarnya (Gnjatovic, 2015).

Dongeng menurut Garzotto (2010) adalah prosses dalam membuat struktur narrative atau terlibat dalam kegiatannya dan meresap masuk dalam banyak aspek kehidupan anak. Sehingga, dongeng dapat diartikan sebagai cerita yang digunakan untuk menyampaikan suatu manfaat, dengan menggunakan imajinasi.

\section{Klasifikasi Dongeng}

Terdapat dua cara dalam mendongeng (Ralibi dalam Ardini, 2012) yakni Mendongeng menggunakan alat peraga dan tanpa menggunakan alat peraga. Menggunak alat peraga berarti menyampaikan cerita menggunakan alat bantu seperti boneka tangan, buku cerita, dan sebagainya. Mendongeng tanpa menggunakan alat peraga berarti Mendongeng tanpa menggunakan alat peraga berarti menggunakan mimik wajah, ekspresi, dan intonasi.

Selain itu, Priyono (Ardini, 2012) mengatakan bahwa klasifikasi dongeng juga berdasarkan isi ceritanya. Yakni Legenda, Fabel, Sahibul Hikayah, Mitos, dan Cerita Rakyat. Legenda adalah cerita yang terdapat pada masyarakat dan berkaitan dengan sejarah. Fabel merupakan cerita yang menggunakan binatang sebagai pemeran dan menceritakan karakter manusia.

Sahibul hikayah adalah cerita yang digunakan untuk mempelejari tingkah laku nabi dana sahabatnya. Mitos menurut kamus besar bahasa indonesia adalah cerita daerah tentang tokoh tertentu seperi dewa dan pahlawan yang berkaitan dengan hal gaib dan menafsirkan cerita tentang asal-usul sebuah peristiwa atau kejadian. Cerita rakyat adalah cerita yang dimiliki masyarakat dan berkaitan dengan budaya suatu daerah (Ardini, 2012).

\section{Dongeng dan Perkembangan Anak}

Dongeng menurut Drgana Gnjatovis. Menjadi bagian penting dari pendidikan prasekolah kurikulum dan praktek awal. Pada masa awal perkembangan ini anak-anak mengebangkan kemampuan berbicara dan literasinya. Dongeng dikatakan sebagai cara yang baik untuk mengembangkan perkembangan anak. anak mampu berimajinasi dan mampu mengambil karakter dan tema, dalam waktu yang berasaamn mereka mampu memlikih selektif dan untuk mengambil jalan ceritanya (Gnjatovic, 2015).

Cerita dalam dongeng akan menjadi asset dalam perkembangan sosial-emosi dan motorik. Peneiltian lain juga menunjukkan bahwa dongeng mampu membantu regulasi diri (Gnjatovic, 2015). Sejalan dengan hal tersebut dongeng menurut Garzotto (2010) membantu perkembangan komunikasi, rekognasi, kemampuan recall, dan membantu mendorong hubungan antar sebaya. Peneliti beranggapan bahwasannya pemberian dongeng dengan bneka berpengaruh menghasilkan beberapa emosi positif pada anak isoa prasekolah

\section{METODE PENELITIAN}

Penelitian ini menggunakan desain eksperimen kuasii, The Nonrandomized Pretest Posttest Control Group Design. Design Penelitian menggunakan dua kelompok variabel, yakni kelompok kontrol dan kelompok eksperimen (diberikan dongeng).

Penelitian dilakukan pada kelas B di TK Muslimat NU 21, dengan rentan usia antara 5 sampai 6 tahun. Hal ini menjadi pertimbangan karena perkembangan kognitif anak pada usia tersebut telah mencapai praoprasional, dimana pembelajaran akan lebh mudah ditangkap melalui interaksi secara langsung dengan melibatkan sentuhan dan emosi.

Pengabilan sampel menggunakan teknik Purposive Sampling dengan 40 orang yang dibagi rata dua kelompok. Dongeng diberikan selama enam harridan dilakukan di dalam kelas karena lebih kondusif serta terkontrol. Dongeng yang diberikan merupakan dongeng menggunakan alat bantu berupa boneka. Penyampaian dongeng diberikan dalam tiga tahap pembukaan, pemberian cerita, dan penutup berupa tanya jawab kepada siswa.

Kelompok kontrol tidak diberikan perlakuan (dalam hal ini dongeng), namun segala perilakunya tetap direkam melalui kamera. Hal ini ditujukan agar perlaku anak anak dalam kelompok kontrol tetap mampu diamati dan 
terpantau perkembangannya meskipun tanpa perilaku untuk nantinya akan dibandingkan dengan kelompok eksperimen di akhir penelitian. Penelitian berlangsung dalam kurun waktu tiga minggu. Minggu pertama berfokus pada observasi perlakuan anak di kelompok kontrol dan eksperimen. Dalam observasi awal ini, dilakukan perekaman dengan waktu tiga hari pada tiap kelompok, sedangkan durasi perekaman berlangsung selama dua jam tiap pengambilan data.

Minggu ke dua mulai dilakukan perlakuan dongeng pada kelompok eksperimen, sedangkan pada kelompok kontrol hanya dilakukan perekaman. Selain perlakuan dongeng, juga dilakukan oservasi lapangan pada perilaku anak selama di berikan dongeng seperti tingkat antusiasme mereka dan kemampuan mereka untuk mengkomunikasikan apa yang mereka dapat dari dongeng yang dismpaikan. Perilaku dongeng serta observasi lapangan ini diberikanenam hari dalam satu minggu, dengan durasi dua jam tiap pertemuan dan pengambilan data.

Minggu ketiga merupakan minggu terakhir dimana dilakukan observasi perlakuan post test pada kedua kelompok. Observasi ini dilakukan selama tiga hari dengan durasi perekaman dua jam pada tiap pengambilan data.

Pengukuran Pretest dan Posttest menggunakan Skala PANAS yang terdiri atas 5 aspek, yakni Interested, Inspired, Excited, strong, dan active,yang kemudian dikembangkan menjadi 49 Aitem. Skala Panas ini kemudian dilakukan dengan mencentang oleh peneliti.

\section{HASIL DAN PEMBAHASAN}

Berdasarkan hasil Penelitian dari data skala PANAS dan lima aspek dari penilitian yakni Interested, Inspired, Excited, strong, dan active. Terdapat hasil sebagai berikut.

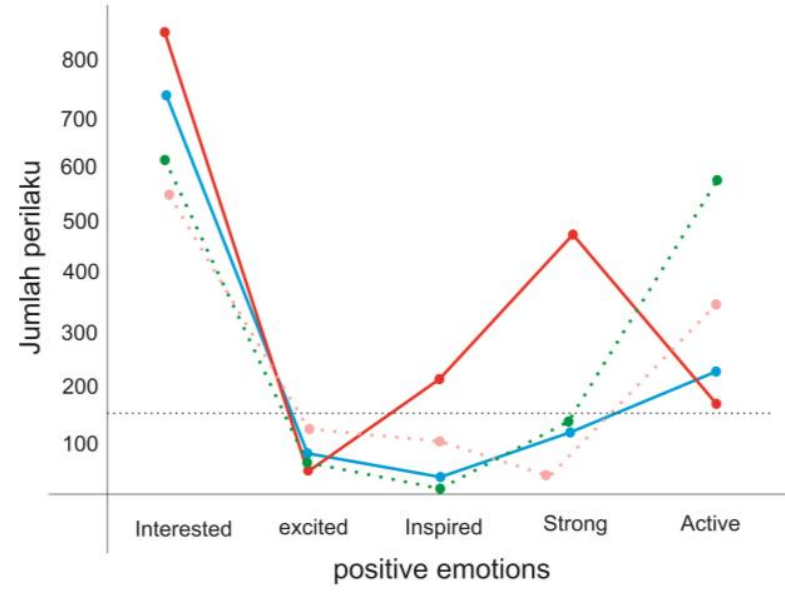

Keterangan

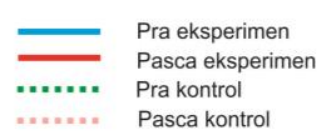

Berdasarkan hasil skala PANAS yang diamati oleh observer, terdapat perbedaan yang terjadi setelah dan sebelum pada kelompok kontrol dan kelompok eksperimen. Pada kelompok eksperimen terdapat perubahan sebesar 41,2\% sedangkan pada kelompok kontrol terjadi 9,34\%. Kelompok eksperimen memiliki perubahan signifikan pada aspek Interested, Inspired, strong, dan active.

Interested terdiri atas indikator kognisi, perasaan,dan konasi. Pada penlitian ini indikator tersebut menunjukkan aspek tertinggi pencapainnya. Terdapat selisih sekitar 12,5\% dari sebelum diberikan dongeng sedangkan pada kelompok kontrol hanya memiliki perubahan yakni $8,3 \%$.

Excited terdiri atas pengetahuan terhadap hal yang ia hadapi, kepastian tentang hal yang diterima, antisipasi sikap dan perilaku saat berinteraksi. Pada aspek ini kelompok eksperimen mengalami penurunan sebanyak $8 \%$. Inspired mempunyai indikator pengalaman, stimulus hal inspiratif, menyadari manfaat dari hal baru. Pada kelompok eksperimen terjadi peningkatan sebanyak 78\%. Berbeda dengan kelompok kontrol yang memiliki penurunan dalam Aspek Strong memiliki kenaikan cukup tinggi dan di indikatori oleh competence, relatedness, dan autonomy. Strong memiliki kenaikan $80 \%$ kemunculan perilaku. Sedangkan kelompok kontrol $33 \%$.

Aspek Active memiliki penurunan pada kelompok eksperimen dan perbedaan yang cukup jauh. Hal ini disebabkan oleh perbedaan hari. 
kegiatan saat mengobservasi kelompok eksperimen dalam suasana belajar duduk dikelas dan guru menerangkan. Sedangkan ketika kelompok pasca kontrol adalah ketika anak melakukan praktek sholat berjamaah.

Berdasarkan grafik tersebut, lima aspek yang paling dominan pada kelompok eksperimen adalah aspek interested, Strong dan Inspired. Sedangkan excited dan Active cenderung mengalami penurunan. Hal ini karena perbedaan jenis kegiatan dua kelompok ketika observasi dilakukan.

Interested, strong, dan Inspired adalah hal yang menonjol dan menunjukkan bahwa adanya peningkatan pada emosi postif. Interested berkaitan dengan kesadaran terhadap sesuatu yang berkaitan dengan dirinya. Strong berkaitan dengan kebulatan tekad, untuk bertanggung jawab pada dirinya, dan Inspired merupakan hal yang memberikan pengaruh dan dapat berupa semangat.

Pengaruh dongeng dalam perkembangan emosi postif berdampak pada tiga hal tersebut. Sesuai dengan penelitian bahwa anak akan mendapatkan komunikasi sosio-emosi yang baik (Gnjatovic, 2015)

Sesuai dengan aspek interested, karena sebagian besar aitem berkaitan dengan bagaimana anak memahami intruksi mengenai objek yang mencakup kemampuan berbehasa (Garzotto, 2010).

Strong atau keteguhan berkaitan dengan motivasi intrinsik. Bagaimana anak memiliki kontrol, merasakan kasih sayng dan pengakuan diri. Dongeng membantu dan memicu hal tersebut.

Autonomy merupakan salah satu indikator dari aspek strong, yang memiliki arti seorang anak selayaknya berkebutuhan untuk bebas akan pengakuan diri. Dalam autonomy sendiri peneliti mengamati perilaku anak yang menunjukkan bahwa

Item pertama, yakni anak mengetahui apa saja yang dia sukai. Dalam aspek ini peneliti mengamati perilaku anak yang berupa anak mau dan bersedia menceritakan apa saja hal yang dia sukai. Sebelum perlakuan kelompok kontrol dan eksperimen menunjukkan jumlah perilaku yang sama, namun pada kelompok eksperimen mengalami peningkatan yang sangat signifikan dibanding kelompok kontrol.

Berbeda denngan item pertama, item kedua kemunculan indikator perilaku setelah dongeng diberikan dari item ke dua dan ketiga menunjukkkan jumlah yang lebih sedikit dibandingkan sebelum dongeng diberikan.

Menurut Kuczynski Active memiliki tiga aspek pokok, yakni 1). Anak secara aktif menciptakan makna tentang apa yang terjadi, 2). Anak bertindak dengan sengaja dalam interaksi, 3). Anak secara kognitif sadar akan kemanjuran tindakannya. Pada aspek pertama terdapat enam indikator perilaku yang secara keseluruhan menggambarkan bagaimana seorang anak membentuk kesan atas apa yang mereka alami, seperti anak membicarakan apa yang sedang terjadi, mereka mengutarakan pendapat tentang sebuah kejadian, membentuk kesimpulan, mengekspresikan perasaannya, ataupun melaporkan temannya.

Hasil dari pengamatan peneliti terdapat perbedaan yang sangat signifikan antara kelompok kontrol dan kelompok eksperimen, dimana kelompok eksperimen menunjukkan peningkatan kemunculan perilaku yang cukup tinggi pada beberapa indikator pasca anak diberikan dongeng sebagai bentuk perlakuan. Adapunn pada kelompok kontrol peningkatan kemunculan perilaku terbilang cukup rendah.

Pada aspek kedua, indikator perilaku disusun untuk memantau tindakan nampak dari interaksi peserta didik seperti mengangkat tangan, mengajukan diri, mengobrol, ataupun mengikuti intruksi. Dalam aspek ini kelompok kontrol menunjukkan lebih banyak kemunculan perilaku dibanding kelompok eksperimen. Hal ini juga dipengaruhi oleh instuksi tambahan dari guru yang mengharuskan anak mengikuti dan menjalankan instruksi tersebut.

Dalam aspek terakhir indikator perilaku diarahkan pada perilaku anak yang didasari inisiatif dan kesadaran anak akan konsekwensi dari tindakannya. Patuh pada perintah guru, menyadari saat di tegur, dan maju saat ingin di beri reward. Di aspek terakhir ini kelompok kontrol menunjukkan lebih banyak kemunculan perilaku dibandingkan kelompok eksperimen. Inspired, yang memberikan pengaruh semangat atau kekuatan untuk melakukan hal tersebut tercermin pada pemberian dongeng. Seperti pada penelitian (Wright dkk, 2012) hubungan pertemanan merupakan salah satu hasil dari aktivitas drama.

\section{KESIMPULAN}

Dari penelitian yang dilakukan, terdapat kenaikan pengaruh dari pra dongeng hingga pasca dongeng. Yakni sebesar 41,2 \% dan 9,34\% 
pada kelompok kontrol. Aspek Interested, strong, dan Inspired adalah hal yang menonjol dan menunjukkan bahwa adanya peningkatan pada emosi postif.

Aspek Excited dan Active mengalami perbedaaan antara kelompok kontrol dan kelompok eksperimen. Kelompok kontrol memiliki hasil yang lebih tinggi. Hal ini disebabkan oleh perbedaan kegiatan ketika melakukan observasi untuk skala PANAS.

Saran untuk penelitian selanjutnya adalah memperhatikan kesamaan kegiatan saat melakukan penilaian Skala PANAS. Penelitian juga dapat dilanjutkan dengan pengeruh dongeng terhadap regulasi emosi dan kemampuan berbahasa.

\section{DAFTAR PUSTAKA}

Ardini, P.P. (2012).Pengaruh dongeng dan komunikasi terhadap perkembangan moral anak usia 7-8 tahun. Jurnal Pendidikan Anak.

Beaty, J. J.( 2013). Observasi Perkembangan Anak Usia Dini. Jakarta: Kencana

Garner, P.W. (1999).Continuity in emotion knowledge from preschool to middle-childhood and relation to emotion socialization. Motivation and Emotion, Vol. 23, No. 4.

Garzotto, F. (2014). Interactive Storytelling for Children.

Gnjatovic, Dragana. (2015). Stories in Different Domains of Child development. University of Malta. DOI: 10.17810/2015.07

Koch, Tina. (1998). Story telling: is it really research?. Journal of Advanced Nursing 28 (6).11821190

Latipun. (2010). Psikologi Eksperimen. Malang: UMM Press

Lily, T. (2010). From Simple Line to Expressive Movement: The Use of Creative Movement to Enhance Socio-Emotional Development in the Preschool Curriculum. 32:100-112 DOI 10.1007/s10465-010-9090-2

Wardani, L.S., Handayani, N., Mahpur, M. (2016) Rekonstruksi Penanaman Nilai Pada anak Melalui Modifikasi Dongeng.(Volume 12. Nomor 2 tahun). Malang: Jurnal psikoislamika.

Masi, R \& Vick, J. (2009). Social-emotional Development in Early Childhood What Every Policymaker Should Know. Janice L. Cooper. colombia university

Stifter, C. A., \& Fox, N. A. (1986) Preschool Children's Ability to Identify and Label Emotions. Journal of Nonverbal Behavior.

Santrock, J.W.( 2011). Perkembangan Masa Hidup. Jakarta: Penerbit Erlangga
Stories in different domains of child development. (2015) Original scientific paper University of Malta UDK: 37.022 DOI: 10.17810/2015.07

Susanto, A. (2011). Perkembangan Anak Usia Dini: Pengantar Dalam Berbagai Aspeknya. Jakarta: Kencana

Székely, E. (2012) . Children's Emotional Functioning in the Preschool Period:

Emotion Recognition, Temperament, and Their Links with Early Risk Factors. Hongarije: Erasmus Universiteit Rotterdam

Wright, C., Diener, M.L., Kemp, J.L. (2012). Storytelling Dramas as a Community Building Activityy in an Early Childhood Classroom. Early Childhood Education Journal. DOI 10.1007/s10643-012-0544-7 